\title{
Developing a Comprehensive Regime for Personal Information Protection in Networked Chinese Public Sectors*
}

\author{
Xiaomi An, Shuyang Sun, Wenlin Bai, Bin Zhang, Xiaoyu Huang, Hepu Deng \\ Renmin University of China, Beijing, China
}

\begin{abstract}
With the increasing sharing and reuse of personal information resources for better public services, the effective protection and management of personal information as organizational and individual assets as well as social resources are becoming more and more important in networked Chinese public sectors. Existing studies of personal information protection in China is mainly conducted from the legal perspective with a focus on the development of appropriate legislation and policies at the national level. There is little research on how specific legislation and polices can actually be implemented in an effective manner and what impacts such legislation and policies have on individuals, organizations, and the society. To adequately address this issue, this study investigates the legal requirements for personal information protection based on the relevant laws, regulations, and standards in China. It proposes a comprehensive regime for personal information protection in the networked public sectors in China. Such a regime takes the advantages of existing discipline-based approaches, legal requirements, and control mechanisms for personal information protection. It can be used to facilitate the provision of public services in the networked Chinese public sectors through the adequate protection of personal information and the effective management of personal information.
\end{abstract}

Keywords: information resources management, personal information, personal information protection, public sector, networked environment, China

\footnotetext{
* Project Supported: Beijing National Social Science Foundation (Project number: 13ZHB013), the Chinese National Social Science Foundation (Project number: 12\&ZD220 \& 13 \&ZD 184), and the Chinese National Natural Science Foundation (Project number: 71133006/ G0314).

Xiaomi An, professor, Key Laboratory of Data Engineering and Knowledge Engineering of the Ministry of Education, Renmin University of China/School of Information Resources Management, Renmin University of China, Beijing, China.

Shuyang Sun, Ph.D. candidate, Key Laboratory Data Engineering and Knowledge Engineering of the Ministry of Education, Renmin University of China/School of Information Resources Management, Renmin University of China, Beijing, China..

Wenlin Bai, Ph.D. candidate, Key Laboratory of Data Engineering and Knowledge Engineering of the Ministry of Education, Renmin University of China/School of Information Resources Management, Renmin University of China, Beijing, China..

Bin Zhang, professor, Key Laboratory of Data Engineering and Knowledge Engineering of the Ministry of Education, Renmin University of China/School of Information Resources Management, Renmin University of China, Beijing, China.

Xiaoyu Huang, associate professor, School of Information Resources Management, Renmin University of China, Beijing, China.

Hepu Deng, professor, School of Information Resources Management, Renmin University of China, Beijing, China/School of Business Information Technology and Logistics, RMIT University, Victoria, Australia.

Correspondence concerning this article should be addressed to Xiaomi An, Room 23, Jingyuan Building 9, Renmin University of China, Beijng, 100872, China. E-mail: anxiaomi@ruc.edu.cn.
} 


\section{Introduction}

Much research has been done in China on personal information protection. Such research is mainly conducted from the legal perspective with a focus on the development of appropriate legislation and policies for personal information protection at the national level in existing Chinese literature (Zhou, 2006; L. Li, 2009; Bai, 2011). There is little research on how specific legislation and polices can actually be implemented in an effective manner and what impacts such legislation and policies have on individuals, organizations, and the society. As a result, there is an increasing demand for developing a comprehensive regime to adequately guide the effective implementation of various personal information protection legislation and polices at an organizational level in order to effectively protect personal information in today's digitalized environment (An, Mu, Wang Wei, Liu, Wang Wang, \& Ye, 2001; Mu, Wang, \& An, 2013).

This study proposes a comprehensive regime for protecting personal information in networked Chinese public sectors. Having taken a multidisciplinary perspective for studying personal information protection, the study identifies the risk control demand in networked public services, the participatory legal regime demand in conformity with laws, and the integrative administrative regime demand for networked services in the public sector. With the adoption of a multi-methods approach including literature review and document analysis, this study investigates the perspectives, legal requirements, and control mechanisms for personal information protection in China. Such an investigation leads to the identification of the legal requirements for personal information protection based on the relevant laws, regulations, and standards in China. As a result, an integrated framework for personal information protection is developed for the public sector in China.

\section{Literature Review}

There are five disciplines involved in the personal information protection in China from literature, including law (Zhou, 2006; Kong, 2009; Shi, 2012), economics (Wu, 2007; X. Li, 2009), sociology (Jing, 2010; Zhou, 2013), information technology (Tao, 2007; Kobayashi, 2007; B. Ding \& Y, Ding, 2012), and information resources management (Ji, 2011; Wu, 2014). In different discipline, why and how personal information should be protected is different for different concerns. To adequately protect personal information, there is a need to develop an integrated framework which can make use of the advantages that individual discipline-based approaches offer in the networked environment.

A meta-synthetic analysis of the applications and the scope of personal information protection under different disciplines reflect the multi-dimensional levels of protection and management controls including national, professional or industrial, and societal systems and services levels. These different levels of protection and management controls are complementary with each other as a comprehensive organic whole. Table 1 presents an overview of the discipline-based analysis of personal information protection with respect to the why and how questions in the Chinese literature.

Table 1

Discipline-based Analysis of Personal Information Protection

\begin{tabular}{|l|l|l|l|l|}
\hline $\begin{array}{l}\text { Disciplinary } \\
\text { perceptions }\end{array}$ & $\begin{array}{l}\text { Disciplinary concerns about protection } \\
\text { (why) }\end{array}$ & $\begin{array}{l}\text { Disciplinary approaches to protection } \\
\text { (how) }\end{array}$ & $\begin{array}{l}\text { Levels of } \\
\text { protection } \\
\text { concerns }\end{array}$ & Sources \\
\hline Law & $\begin{array}{l}\text { Protect privacy right, respect personality } \\
\text { and human dignity. }\end{array}$ & $\begin{array}{l}\text { legislation for protection of privacy } \\
\text { right, right to be informed, tort, etc. }\end{array}$ & National & $\begin{array}{l}\text { Zhou (2006), } \\
\text { Kong (2009), and } \\
\text { Shi (2012) }\end{array}$ \\
\hline
\end{tabular}


Table 1 to be continued

\begin{tabular}{|c|c|c|c|c|}
\hline $\begin{array}{l}\text { Disciplinary } \\
\text { perceptions }\end{array}$ & $\begin{array}{l}\text { Disciplinary concerns about protection } \\
\text { (why) }\end{array}$ & $\begin{array}{l}\text { Disciplinary approaches to protection } \\
\text { (how) }\end{array}$ & $\begin{array}{l}\text { Levels of } \\
\text { protection } \\
\text { concerns }\end{array}$ & Sources \\
\hline Economics & $\begin{array}{l}\text { From business perspective, customer's } \\
\text { personal information is important } \\
\text { strategic asset of business. From user's } \\
\text { perspective, consent of access to } \\
\text { personal information needs a balance } \\
\text { between information leak and the } \\
\text { economic benefits from the services. }\end{array}$ & $\begin{array}{l}\text { code of professional society, industry } \\
\text { best practice, protection of customer's } \\
\text { asset, balance between property rights } \\
\text { and the civil rights }\end{array}$ & $\begin{array}{l}\text { Professional } \\
\text { or Industrial }\end{array}$ & $\begin{array}{l}\text { Wu (2007) and } \\
\text { X. Li (2009) }\end{array}$ \\
\hline Sociology & $\begin{array}{l}\text { Maintain social order to protect human } \\
\text { dignity and civil rights and to avoid } \\
\text { misconduct and negative impacts. } \\
\text { Behavior of information collecting, } \\
\text { storage and access should be in } \\
\text { conformity with moral rights and ethics } \\
\text { norms as well as code of conduct. } \\
\text { Balance of easy access and use of } \\
\text { personal information and the privacy } \\
\text { protection on line. }\end{array}$ & $\begin{array}{l}\text { awareness of obligations for personal } \\
\text { information protection and the ethics. }\end{array}$ & Societal & $\begin{array}{l}\text { Jing (2010) and } \\
\text { Zhou (2013) }\end{array}$ \\
\hline $\begin{array}{l}\text { Information } \\
\text { technology }\end{array}$ & $\begin{array}{l}\text { Internet provide convenience and new } \\
\text { opportunities of creating new services } \\
\text { and new products through access to } \\
\text { personal information and the same time } \\
\text { bring challenges to security of services } \\
\text { and products. For economics and } \\
\text { emerging technology benefits. }\end{array}$ & $\begin{array}{l}\text { security management, IT artifacts for } \\
\text { protection or control of information } \\
\text { privacy, protocols, IP password, } \\
\text { real-name authentication, etc. }\end{array}$ & Systems & $\begin{array}{l}\text { Tao (2007), } \\
\text { Kobayashi } \\
\text { (2007), and } \\
\text { B. Ding and Y. } \\
\text { Ding (2012) }\end{array}$ \\
\hline $\begin{array}{l}\text { Information } \\
\text { resources } \\
\text { management }\end{array}$ & $\begin{array}{l}\text { Avoid leak and violation of personal } \\
\text { information that bring harms to mind } \\
\text { and interests, for public interests, public } \\
\text { administration, and national security. }\end{array}$ & \begin{tabular}{|l} 
entire life control of \\
information through collection, \\
and access; collageral \\
between services providers, system \\
developers, and information subject
\end{tabular} & Services & $\begin{array}{l}\text { Ji (2011) and } \\
\mathrm{Wu}(2014)\end{array}$ \\
\hline
\end{tabular}

\section{Research Methods}

Based on review of literature, multi-disciplinary perspectives and multi-dimensional levels of protection and management controls including national, professional or industrial, and societal systems and services levels are assumed as an organic whole for top down design of a comprehensive regime for personal information protection. Investigation of legal warranty is selected as the appropriate way to know how specific legislation and polices can actually be implemented in an effective manner and what impacts such legislation and policies have on individuals, organizations, and the society towards developing a comprehensive regime for personal information protection in networked environment.

The official documents that are relevant to protection and management of personal information along their lifecycle are collected, which includes four national plans, 29 laws, and four specific regulatory requirements for personal information protection in networked environment. Legal warranty analysis has been done to know demands for and controls of personal information protection throughout the process of collection, processing, storage, and access in networked public services.

\section{Warranty for Personal Information Protection in Networked Chinese Public Sectors}

The enhancement of the capacity for providing quality information services in recent years in China is highlighted in various national plans (Ministry of Industry and Information Technology [MIIT], 2012; The 
State Council, 2013; Ministries, 2014; The Chinese Communist Party Central Committee \& The State Council, 2014) for better public services to citizens. The sharing and reuse of personal information resources including personal information collected, processed, and used by government bodies across departments, professional associations, and regions are encouraged for the optimized allocation of public goods, the development of collaborative businesses, good governance, and social management innovation, faster, easier, and convenient one-stop public services. This leads to an increasing recognition of the importance of adequately protecting personal information for their shared use in conformity with the laws, regulations, and policies in a networked environment.

There are few action plans and management mechanisms for the protection of personal information throughout the sharing and reuse of personal information. To adequately protect personal information, there is a demand for the risk control of personal information along the lifecycle of personal information throughout the process of collection, processing, storage, and access in networked public services. Table 2 presents an overview of the demand for the risk control of personal information in various national plans in China.

Table 2

Demands for Risk Controls of Personal Information in National Plans

\begin{tabular}{|l|l|l|}
\hline Name of national plan & Purpose of information sharing and reuse & $\begin{array}{l}\text { Risk control demands for personal } \\
\text { information protection }\end{array}$ \\
\hline $\begin{array}{l}\text { The twelfth five year plan of } \\
\text { national e-government in } 2012\end{array}$ & $\begin{array}{l}\text { social management innovation, collaborative } \\
\text { business }\end{array}$ & $\begin{array}{l}\text { connected processes, systems and public } \\
\text { services, benefit to people }\end{array}$ \\
\hline $\begin{array}{l}\text { Opinions on promotion } \\
\text { information consumption of China } \\
\text { in } 2013\end{array}$ & $\begin{array}{l}\text { information consumption, new market and, } \\
\text { economy }\end{array}$ & $\begin{array}{l}\text { enhance personal information protection and } \\
\text { information security to build a secured, } \\
\text { trusted, and well-organized information } \\
\text { consumption market environment }\end{array}$ \\
\hline $\begin{array}{l}\text { Notice of work relevant to } \\
\text { fostering implementation of } \\
\text { information services project } \\
\text { benefit to people in 2014 }\end{array}$ & $\begin{array}{l}\text { one stop public service, enhancement of } \\
\text { capacity of information services and public } \\
\text { service benefit to people }\end{array}$ & $\begin{array}{l}\text { information resources integration and sharing } \\
\text { for collaborative business, supervision, and } \\
\text { services across different administrative levels } \\
\text { and departments }\end{array}$ \\
\hline $\begin{array}{l}\text { National new types of city and } \\
\text { town planning in 2014 }\end{array}$ & $\begin{array}{l}\text { new types of information services, promote IT } \\
\text { applications in urban planning management, } \\
\text { intelligence of infrastructure, easier public } \\
\text { service, modernization of industry } \\
\text { development, and refined social governance }\end{array}$ & $\begin{array}{l}\text { government information sharing and } \\
\text { collaborative business across departments, } \\
\text { professional fields, and regions }\end{array}$ \\
\hline
\end{tabular}

An investigation of the laws which have concerns about protecting personal information from the most comprehensive Chinese legislation and regulation database (pkulaw.cn) shows that there are 29 laws relevant in China. Table 3 shows an overview of the legal requirements for personal information protection through the processes of personal information management along the lifecycle of personal information with respect to (1) collection (eight items), (2) registration (one item), (3) security and confidentiality (26 items), (4) access and sharing (three items), (5) exceptions to access and sharing (26 items), (6) disposition and custody (two items), and (7) penalties (18 items).

There are disparate and separated approaches to personal information protection in China according to different laws. This is undesirable in today's dynamic and networked environment for providing citizens with quality public services. There is a need for developing a collaborative legal regime to integrate administrative systems, technology measures, and different ways of penalty controls to security and confidentiality of personal information that can provide a holistic approach to adequately protect personal information. Such a comprehensive regime can cover all the processes and all the activities of information resources management 
along the lifecycle of personal information resources in conformity with existing laws.

An investigation of the laws, regulations, and policies relevant to personal information protection specific to a networked environment from the pkulaw.cn shows that there are no specific laws available with a special regard to the networked environment. Four relevant regulations and policies (Standing Committee of the National People's Congress, 2012; MIIT, 2013a, 2013b; The State Administration for Industry and Commerce, 2014) can be found in this regard.

Table 3

Legal Requirements for Personal Information Protection and Processes of Information Resources Management

\begin{tabular}{|l|l|l|}
\hline $\begin{array}{l}\text { Information resources } \\
\text { management processes }\end{array}$ & Legal requirements & Number of laws \\
\hline Collection & $\begin{array}{l}\text { collection by fair and lawful means; collection should be limited for specified } \\
\text { business functions and law purpose; consent of the data subject }\end{array}$ & 8 \\
\hline Registration & lawful procedure of registration & 1 \\
\hline Security and confidentiality & $\begin{array}{l}\text { professional duty; appropriate security safeguards and classified levels of security } \\
\text { controls; authorization of access }\end{array}$ & 26 \\
\hline Access and sharing & $\begin{array}{l}\text { lawful procedure in accessing personal information; nondisclosure of personal } \\
\text { information in access and sharing; consent of the information subject for lawful } \\
\text { and functional use }\end{array}$ & 3 \\
\hline $\begin{array}{l}\text { Exceptions to access and } \\
\text { sharing }\end{array}$ & Disclosure, sell, and unlawful providing personal information are not allowed & 26 \\
\hline Disposition and custody & $\begin{array}{l}\text { data should be processed fairly and lawfully; security protection of personal } \\
\text { information; personal information retained only to fulfill the stated purpose. } \\
\text { Irrelevant information needs to be securely destroyed }\end{array}$ & 2 \\
\hline Penalty & order to correct; pecuniary penalty; administrative sanction; criminal punishment & 19 \\
\hline
\end{tabular}

The importance of protecting personal information in networked public services is getting increasingly recognized in China in recent years. There are many regulations and policies that are designed for business and industry sectors, network services providers, relevant enterprise units, manufacturers, and working staffs in China. Table 4 provides an overview of the regulations and policies related to the protection of personal information in the provision of networked public services. The public sector, however, is inadequately covered under such regulations and policies. This shows that there is a demand for the development of a participatory regime for personal information protection to include networked Chinese public sectors for the provision of networked public services.

Table 4

Regulations and Policies Concerned With Personal Information Protection for Networked Services

\begin{tabular}{|l|l|l|}
\hline Name of regulations and policies & To whom and where & $\begin{array}{l}\text { Types of personal information for } \\
\text { protection }\end{array}$ \\
\hline $\begin{array}{l}\text { Decision on the standing committee of the national } \\
\text { people's congress on strengthening information } \\
\text { protection on networks in 2012 }\end{array}$ & $\begin{array}{l}\text { network service providers, other } \\
\text { relevant enterprises units and staff }\end{array}$ & $\begin{array}{l}\text { citizen's electronic personal } \\
\text { information }\end{array}$ \\
\hline $\begin{array}{l}\text { Provisions on protecting the personal information of } \\
\text { telecommunications and internet users in 2013 }\end{array}$ & $\begin{array}{l}\text { telecommunication services } \\
\text { managers and internet information } \\
\text { services providers }\end{array}$ & users personal information \\
\hline $\begin{array}{l}\text { Notice of the Ministry of Industry and Information } \\
\text { Technology on strengthening the network access } \\
\text { management of mobile intelligent terminals in 2013 }\end{array}$ & $\begin{array}{l}\text { mobile intelligent terminals } \\
\text { production enterprises }\end{array}$ & users personal information \\
\hline Administrative measures for on line trading in 2014 & $\begin{array}{l}\text { network products mangers, relevant } \\
\text { service managers and the work staff }\end{array}$ & consumer's personal information \\
\hline
\end{tabular}




\section{Toward a Comprehensive Regime for Personal Information Protection}

There are four polices and one standard as shown in Table 5 that provide three directional controls for personal information protection in networked services in China. The three controls include (1) the risk control by classification of personal information into personal general information and sensitive information, (2) the security control by classification of personal information into electronic personal identity information and electronic personal privacy information, and (3) the user control by classification of personal information into user identifiable information and user information. Though the applications of polices and standards are specific to the business and industry sectors, they are universal to networked services including networked public services, which have broader implications to networked public sectors.

Table 5

Control Methods for Personal Information Protection

\begin{tabular}{|l|l|l|}
\hline $\begin{array}{l}\text { Types of personal } \\
\text { information protection } \\
\text { control methods }\end{array}$ & Methods for personal information protection control & Sources \\
\hline Risk control & $\begin{array}{l}\text { lassification of personal information into two categories for different } \\
\text { levels of control: general information_personal information that are not } \\
\text { sensitive information; personal sensitive information_personal } \\
\text { information that can bring negative impacts to identifiable information } \\
\text { subject once it is leaked or revised, such as identification card number, } \\
\text { telephone number, nationality, political attitude, religions, DNA, } \\
\text { fingerprint, etc. }\end{array}$ & $\begin{array}{l}\text { Personal information protection } \\
\text { guidelines for public and } \\
\text { commercial service information } \\
\text { system of information security }\end{array}$ \\
\hline Security control & $\begin{array}{l}\text { identification of electronic information that can identify personal identity } \\
\text { and privacy for security control }\end{array}$ & $\begin{array}{l}\text { Decision on strengthening the } \\
\text { network information protection } \\
\text { in 2012 }\end{array}$ \\
\hline User control & $\begin{array}{l}\text { identification of user's and consumer's personal information in the } \\
\text { processes of the provision of internet services for security control, such } \\
\text { as user name, birth date, identification card number, address, telephone } \\
\text { number, account number, password, and other information that } \\
\text { combined together to identify users and consumers, their time and place } \\
\text { of access of the services }\end{array}$ & $\begin{array}{l}\text { Provisions on protecting the } \\
\text { personal information of } \\
\text { internet users in 2013 and } \\
\text { Administrative measures for on } \\
\text { line trading in 2014 }\end{array}$ \\
\hline
\end{tabular}

Converging the above multi-disciplinary perceptions and multi-dimensional levels of personal information protection controls as shown in Table 1 with the multi-directional control methods from polices and standards in Table 5, Figure 1 presents a participatory governance framework to cover various methods of adequate controls as an integrative new whole for the protection of personal information.

The proposed framework takes advantages of diversified personal information protection approaches as a collaborative and comprehensive regime with legal warranty. Five disciplinary approaches are integrated as complementary: (1) the protection control as legal requirements from legislation under perception of law, (2) the security control as moral rights and ethics from social obligations under perception of sociology, (3) the risk control as benefits for both customers and business from professional code under perception of economics, (4) the user control as properties of products from information systems under perception of information technology, and (5) the protection and management control throughout the life of personal information as efficient and effective public services through effective government information resources management. 


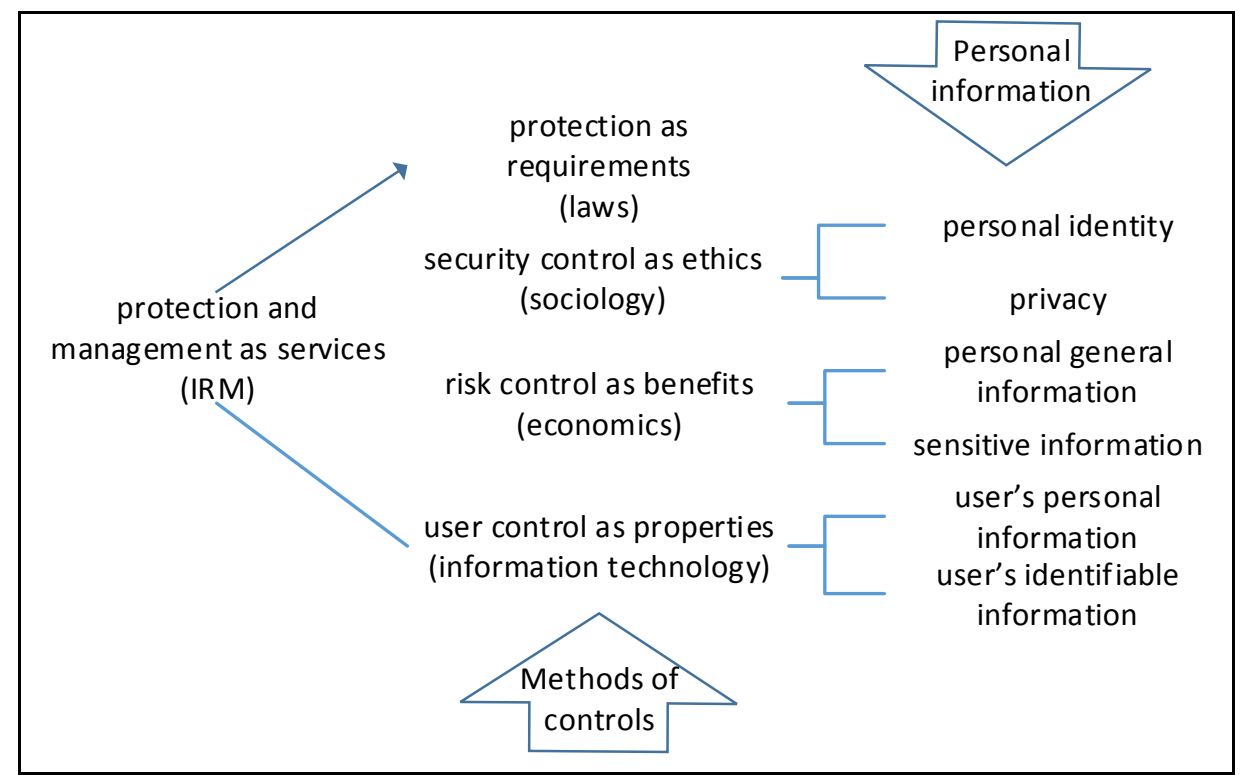

Figure 1. A comprehensive regime for personal information protection with legal warranty.

\section{Conclusions}

This study rationalizes a legal warranty approach to develop a comprehensive regime for personal information protection in the networked Chinese public sector. Three warranties are identified including the risk control for personal information protection in their sharing and reuse in networked public services, the participatory regime in conformity with legislation, and an integrative administrative regime with a special regard to networked services.

The study proposes a comprehensive regime for personal information protection in networked public sectors based on a holistic review of multi-disciplinary perceptions of personal information, multi-dimensional levels of personal information protection controls, and multi-directional control methods. The regime consists of three key aspects including (a) an adequate classification of personal information for risk control with respect to multitude perceptions of personal information preservation, (b) a participatory personal information protection legal regime for personal information protection along the entire life-cycle of personal information and the processes of personal information resources management in conform with the legal requirements, and (c) an integrative personal information protection framework to balance the protection and the secured sharing and reuse of personal information for the enhancement of networked public services.

The study defines personal information as organizational and individual assets for protection as well as social resources for innovation of social management and better public services. It takes the advantages of existed disciplinary approaches, legal requirements, and control mechanisms for personal information protection as a complementary and integrative organic whole. It contributes to networked Chinese public sectors for personal information resources protection and management along the life of government information and throughout the processes of government information resources management. It can be used to facilitate the provision of public services in the networked Chinese public sector through the adequate protection of personal information and the effective management of personal information with legal warranty. This paper is limited, because it's only on the development of a conceptual work, justification studies by surveys, interviews, and web sites visits which have been done and will be discussed in another paper. 


\section{Reference}

An, X., Mu, Y., Wang Wei, Liu, J., Wang Wang, \& Ye, L. (2011). Analysis of current legal and regulatory requirements for personal information protection and management in China. Beijing Archives, 5, 19-21.

Bai, H. (2011). Studies about legal problems of network personal information protection (Unpublished master's thesis, Minzu University of China, Beijing, China).

Ding, B., \& Ding, Y. (2012). Model of personal information protection based on relationship networks. Library and Information Service, 56(2), 50-54.

Ji, X. (2011). On rational utilization of personal information. Information Research, 11, 20-21.

Jing, S. (2010). Problems of tort of network personal information. Youth Journalist, 3A, pp. 55-56.

Kobayashi, M. (2007). IT development and personal information protection. Beijing: Economic Daily Press.

Kong, L. (2009). Privacy protection of personal data. Wuhan: Wuhan University Press.

Li, L. (2009). Legal development report No.7. Beijing: Social Science Documentation Publishing House.

Li, X. (2009). Logics of network consumer's personal information right: Evolution of economical patterns. Social Scientist, 10, 67-70.

Ministries. (2014). Notice of work relevant to fostering implementation of information services project benefit to people. Retrieved from http://www.mof.gov.cn/zhengwuxinxi/zhengcefabu/201401/t20140116_1036140.htm

Ministry of Industry and Information Technology. (2012). The twelfth five year plan of national e-government (Announcement). Retrieved from http://www.miit.gov.cn/n11293472/n11295327/n11297217/14562026.html

Ministry of Industry and Information Technology. (2013a). Notice of the Ministry of Industry and Information Technology on strengthening the network access management of mobile intelligent terminals. Retrieved from http://opinion.news.chengdu.cn/topic/2013-10/31/content_1305121.htm?node=12022

Ministry of Industry and Information Technology. (2013b). Provisions on protecting the personal information of $\begin{array}{lllll}\text { telecommunications } & \text { and } & \text { users. } & \text { Retrieved }\end{array}$ http://www.miit.gov.cn/n11293472/n11294912/n11296542/15514014.html

$\mathrm{Mu}$, Y., Wang, W., \& An, X. (2013). Personal information protection system in government agencies. Information Construction, $1,22-25$.

Shi, J. (2012). Legislation of personal information protection in networked environment. Suzhou University Academic Journal, 6 , $85-96$.

Standing Committee of the National People's Congress. (2012). Decision on the standing committee of the national people's congress on strengthening information protection on networks. Retrieved from http://news.hexun.com/2012-12-28/149603728.html

Tao, J. (2007). Protection of personal data privacy in networked age. Front, 5, 119-121.

The Chinese communist Party Central Committee., \& The State Council. (2014). The national new urbanization planning (2014-2020). Retrieved from http://politics.rmlt.com.cn/2014/0317/244361.shtml

The State Administration for Industry and Commerce. (2014). Administrative measures for on line trading. Retrieved from http://www.law-lib.com/law/law_view.asp?id=443546

The State Council. (2013). Opinions on promotion information consumption of China. Retrieved from http://www.js.xinhuanet.com/2013-08/15/c_116951133.htm

$\mathrm{Wu}, \mathrm{G}$ (2007). On the balanceable relationship between protection and utilization of personal information. Information Science, 25(1), 47-49.

Wu, Y. (2014). Protecting personal data in e-government: A cross-country study. Government Information Quarterly, 31(1), $150-159$.

Zhou, H. (2006). Research front of personal information protection. Beijing: Legal Publishing House.

Zhou, S. (2013). Abuse and relief of personal information in network group events. Beijing Social Science, 1, 11-16. 